\title{
The Effect of Electronic Word-Of-Mouth (EWOM) On Brand Im- age and Purchase Intention: A Conceptual Paper
}

\section{Hussam Al Halbusi}

PhD Candidate, Department of Business Strategy and Policy, Faculty of Business and Accountancy, University of Malaya, Malaysia

\section{Shehnaz Tehseen}

PhD, Lecturer, Sunway University Business School, Sunway University, Malaysia

\begin{abstract}
This paper summarizes the arguments and counterarguments within the scientific discussion on the issue of Electronic Word-of-Mouth (eWOM) on brand image and purchase intention. The main purpose of the research is to investigate the effect of Electronic Word-of-Mouth (eWOM) on brand image and purchase intention, a study on Malaysia's automobile industry focusing on Malaysian branded cars. Systematization literary sources and approaches for solving the problem, before we embark to the details of this research, the paper will give a synopsis of the study indicates that purchase intention. The relevance of the decision of this scientific problem is that many studies need an Investigation of the topic of Electronic Word-of-Mouth (eWOM) on brand image and purchase intention. In the paper is carried out in the following logical sequence Methodological tools of the research methods were done huge reviews of the pervious researches. The object of research is the chosen Malaysia's automobile industry focusing on Malaysian branded cars, because namely they have an intention of the customers. The paper presents the results of past studies and showed that the new proposed framework. The research proposed future direction and potential solution of the issues. Initially this will highlight commence with a research background followed by a problem statement then significance of the study which will eventually be trailed with the research questions, research objectives and lastly, limitations will be elucidated.
\end{abstract}

Keywords: electronic word, Electronic Word-of-Mouth (EWOM), brand image, brands, purchase intention, buy intention.

\section{JEL Classification: M.}

(C) The Authors, 2018. This article is published with open access at Sumy State University.

\section{Introduction}

In times at which consumers' reliance on companies as well as adverts has declined excessively, WOM has contributed means to attain important benefits. With the current digitized surroundings, eWOM has become among the most impactful mediums of acquiring, evaluating and deducing impact that an individual can influence on others through the internet (Jalilvand \& Samiei, 2012).

Researches demonstrated WOM communications to have greater impact compared to other mediums of communication such as ads, that was justified to the reason that trustable information are obtained through WOM communications (Mauri and Minazzi, 2013; Browning and Sparks, 2011). Apart from that, research also shows that only $14 \%$ of consumers believe on what ads advertise. What's astonishing is that from every 9 of every 10 consumers believe in their relatives, friends as well as their work mates since they won't get any advantage for favoring a product or service (Nakhaee \& Kheiri, 2012). Besides that, with the growing internet use as a tool to communicate and advertise, WOM ads enormously developed (Jalilvand \& Samiei, 2012). As communication of WOM initially meant a conversation between individual-to-individual nevertheless with the global internet outburst, communications of WOM eventually expanded to what is currently recognized eWOM (Serra Cantallops \& Salvi, 2014).

eWOM inculcates various media channels as well as online portal whereby outmost accessibility to reviews among consumers is existing (Nakhaee \& Kheiri, 2012). Generally, eWOM communications enables an individual to have an impact on the purchasing intention of consumers based on the information illustrated (East, et al., 2007). Henceforth, communication through WOM immensely impacts the attitude of a consumer while making a decision as well as minimizes risks pertaining to the acquisition (Liu and Park, 2015; Bronner and de Hoog, 2011; Zhang et al., 2010). 
According to World Intellectual Property Report (2013), the image of a brand has the tendency to impact firm's earning, consumers' intention to buy as well as their marketing's success which all will consequently impact their sustainability in the long run. In this perspective, as WOM have a vital impact to the intention of purchasing a product, eWOM have a further higher impact on the image of the product as well as the intention to purchase the product of a brand due to its global proximity of disseminating information (Filieri \& McLeay, 2014; Smith, Menon, \& Sivakumar, 2005; Senecal \& Nantel, 2004).

Despite the fact that, there has been an increment of $1.5 \%$ of Malaysia's total sale of automobile units from 655,793 to 665,675 (2013-14), it is astonishing to see why local Malaysian branded cars has declined its market share from 59\% (2009) to 47\% (2014) of the total number of cars sold in Malaysia, which is a constant decline since 2009 for Malaysian branded cars while an opposite phenomenon for foreign branded cars (Paultan, 2015) in spite foreign cars are levied with high excise duties (Malaysian Automotive Assocciation, 2014).

As the level of competition keep on increasing in Malaysia automobile market, it is essential for Malaysian automobile producer companies to understand customer insight in order to further increase their market share. Thus, they need to understand what factors might influence their customers' decision in purchasing an automobile. Therefore, this research aims to study the effect of electronic-Word-of-Mouth (eWOM) on brand image and purchase intention. A study on Malaysia's automobile industry focusing on Malaysian branded automobiles.

\subsection{Significance of the study}

Despite there are some research studies that examines the branding of consumers goods and an increasing literature on product brands, little is known about brand image in the context of online communications. Thus, this research paper will provide valuable insight into eWOM, brand image, and purchase intention in the automobile industry of Malaysia by promoting local brands effectively and will offer a foundation for future product branding research. The contribution will mainly be to the academia, automobile companies and the government which is further explained below.

The study will significantly contribute to the academia in having more research in the field of eWOM marketing, as it will provide a profound insight on the effect of eWOM on brand image and purchase intention in the Malaysian automobile industry, which can be helpful to not only Malaysia but also other countries as it can be a base for any other research to be conducted.

The impact of eWOM is very important for the automobile companies especially to their marketing managers to understand the behavior of the consumers pertaining to how consumers perceive their products which is usually recognized from its brand, from the negative or positive feedbacks. So Marketing managers can create appropriate medium of communication that will enhance consumers' knowledge pertaining to their brand. Apart from that, they can also attempt to amend any negative views consumers might have pertaining to their brand using eWOM, which will thus create positive brand image, that will consequently reduce their marketing expenses as well as increase consumers' tendency to buy their brand.

It is without doubt, the contribution of the research to the government is significant as they can get to develop workshops or seminars to help Malaysian branded cars to better market themselves through eWOM to ensure the automobile industry meets the projected target in contributing $10 \%$ of Malaysia's GDP and an additional workforce of 150,000 by 2020 , of which 70,000 will contribute to the sector of manufacturing while the rest $(80,000)$ will contribute to the sector of post purchase services. Apart from that, they can also be able in assisting the Malaysian branded cars to be better position themselves which will aid their vision to be competitive in not only inbound market but also outbound market by 2020 (MAA, 2014).

To sum up in a nutshell, chapter one has been able to introduce the reader to the most basic fundamentals of this research paper. The background study gave an insight of the whole research. Moreover, the gaps were clearly identified in the problem statement and through a proper identification of the research objectives and questions; the paper was able to explain on how the gaps are going to be closed. Moreover, the significance of the study was also elaborated and it explained how this research paper will benefit the academia, automobile companies as well as the government. Lastly, the limitations and scope of the study were also clearly elucidated. 


\section{Literature review}

\subsection{An overview}

In this section, there will be a critical discussion of the literatures pertaining to this research. The chapter will then be followed with the hypothesis summary which will be consequently trailed with the conceptual framework of this study. Eventually, a chapter summary will also be outlined.

\subsection{WOM to eWOM}

According to Pride and Ferrell (2014), they defined WOM to be personal communicational interchange of consumer information that is conversed to others pertaining to goods, brands, and organizations. Whereas, according to Armstrong and Kotler (2013), they defined WOM to be the influence of words and suggestion of friends on individual/individuals trusted, acquaintances as well as other customers on behavior of purchase. Whereas, other researchers referred WOM to be spoken communication among actual consumer and prospective consumers as well as other individuals or groups such as relatives, friends, brokers, professionals (Jalilvand \& Samiei, 2012; Xie et al., 2011).

Consumers have benefitted immensely through the eWOM with great thanks to the internet compared to the orthodox WOM. eWOM has many advantages such as the swiftness, promptness and accessibility of information, its extensive obtainability duration, without the need of physical presence in a place one intends to disseminate the information such as virtual communication of (Luo and Zhong, 2015; Serra Cantallops and Salvi, 2014; Mauri \& Minazzi, 2013). eWOM inculcates various online portals whereby outmost accessibility to reviews among consumers is existing (Nakhaee \& Kheiri, 2012).

WOM's contribution in theory as well as practice of marketing cannot be argued, with the current era that is driven through technology, swiftly reachable and at the same time universally interconnected, people's opinion as well as advice is playing a significant role in influencing consumers in their preferences and decisions, which they regularly undertake to purchase goods and services (Riegner, 2007). The impact which formerly used to influence only a community at large which is WOM has now been influencing the world at large which is eWOM with the growth of internet everywhere across the globe, has incontestably caused a revolution in the field of marketing (Meiners, et al., 2010).

What's more astonishing is according to a prominent consulting firm named Booz \& Co. (2012), eWOM have become the trend in digital related research topics, especially pertaining to communications among consumers, which they have in fact advised firms to make their customers as their supporters; by shifting the marketing paradigm to facilitating discussions amid consumers rather than conveying messages directly to consumers. Consumers have been utilizing numerous internet podiums to share their experiences pertaining to goods assessment as well as commerce such as through company websites, discussion forums, social media, private agencies, chat rooms, emails, blogs, instant messaging (Fang, 2014; Lovett, Peres, and Shachar, 2013; Mauri and Minazzi, 2013; Punj, 2013; Browning and Sparks, 2011).

eWOM is generally an association of factors that's behaviorally driven by many motives such as to interactively socialize, maintain social relations, to be recognized, to demonstrate support, to obtain joy through activities that are available online esteem (Munar and Jacobsen, 2014; Hennig-Thurau et al., 2004). Though, at Facebook, whereby people are accustomed to forming networks where their written view are credible since the users increase their social base as well as their regularity and period of personal relation, in comparison to another podiums whereby some are limited and less credible (Luo and Zhong, 2015). Whereas according to O'Connor (2008), as dissatisfied consumers had abilities to disseminate their unfavorable experiences among their close circle, with the advancement of technology that led to eWOM, they can now impact a vast number of consumers by utilizing their various social platforms which can be Twitter, Myspace or/and Facebook.

Moreover, in times at which consumers' reliance on companies as well as adverts has declined excessively, WOM has contributed means to attain important benefits. With the current digitized surroundings, eWOM has become among the most impactful mediums of acquiring, evaluating and deducing impact that an individual can influence on others through the internet (Jalilvand \& Samiei, 2012).

Researches demonstrated WOM communications to have greater impact compared to other mediums of communication such as ads, that was justified to the reason that trustable information are obtained through WOM communications (Mauri and Minazzi, 2013; Browning and Sparks, 2011). Apart from that, research also shows that only $14 \%$ of consumers believe on what ads advertise. What's astonishing is that from every 9 of every 
10 consumers believe in their relatives, friends as well as their work mates since they won't get any advantage for favoring a product or service (Nakhaee \& Kheiri, 2012). Besides that, with the growing internet use as a tool to communicate and advertise, eWOM ads enormously developed (Jalilvand \& Samiei, 2012). As communication of WOM initially meant a conversation between individual-to-individual nevertheless with the global internet outburst, communications of WOM eventually expanded to what is currently recognized eWOM (Serra Cantallops \& Salvi, 2014).

Reviews that are written online have grown into gaining significant importance as a means of enabling buyers to obtain not only comprehensive but also relied evidences (Gretzel, Fesenmaier, Lee, \& Tussyadiah, 2011; Yoo \& Gretzel, 2008). The extent of information that have been disseminated online among consumers is unmatchable and detailed (Libai, Muller, \& Peres, 2013; Lovett et al., 2013), comprising primary WOM (PWOM) as well as secondary WOM (SWOM). Information that are obtained consumers' personally from their own experiences is classified to be PWOM, whereas, information that is disseminated from experiences of other consumers which they heard of is classified to be SWOM. Original source of SWOM can be sketched back to ads, business articles or may be from previous experiences that can be primarily or even secondarily attained. As SWOM commercially contributes seventy percent of eWOM, its prejudices associated with it are very vital for goods, trademarks as well as events of marketing (Meiners, Schwarting, \& Seeberger, 2010).

There are many advantages of electronic business in comparison to orthodox business of obtaining customers (Yao, et al., 2009), among the advantages of electronic business is available online is eWOM's availability, apart from swiftness of obtaining information is related to purchase, ease of obtaining information by means of public orientation, obtaining communal feel of belongingness, obtain commercial reward and to get knowledge of using goods. Nevertheless, making good choices and saving time to make choices is the major motive (Hennig-Thurau \& Walsh, 2003). Due to much motives, organizations are fascinated to provide eWOM to be their tool as their free sales support (Chen \& Xie, 2008).

\subsection{Brand image}

According to Keller (1998), he defined brand image to be a way how consumers perceive a brand to be and reflects what their mind have associated the brand to. The relations are based on various dimensions as well as contain emotions or attitude towards the brand image apart from the expected quality. Pertaining to the general view of the experiences of consumers is vital as only by this way, they can form emotional, cognitive as well as behavioral reactions of consumers to be the consequence (Padgett \& Allen, 1997). Whereas, according to Moore (1981), he viewed image to be a psychological approximation to an overall level of being satisfied by a firm's undertakings and enactments. As it is by evaluating the image perceived by the consumers, firms can understand the consumers' attitude to their organizations, by analyzing what the consumers expect and whether the firm has fulfilled their promises.

Furthermore, it is stated by Gardner and Levy (1995), conveyance of one's firm image to targeted consumer has been a vital to marketers' activities since decades ago. As when marketers possess descent capabilities pertaining to the selection of brands, which in other words means getting to a market at the outset afore other players and developing as well as managing firms' brand image throughout will ensure the firm's brand to be sustainable in the long run. Moreover, Park, Jaworski, and Maclnnis (1986) pointed out that image of a brand is a tactical method that drives the objective of supporting brand's idea to be complete through exercising management of brand. Whereas, according to Schiffman and Kanuk (1986), firms should focus on creating relations among consumers that are auspicious and optimistic in order to have a brand that has an image that is positive.

According to Sandesa and Urdana (2013), they view WOM's communicational vitality to be indisputably important to executives in particular to experts of marketing to evaluate behaviors of consumers. WOM is a result of various bases that leads to either negative WOM (NWOM) or positive WOM (PWOM) which are proved to have an impact on other consumers' behavior. For this reason, many industries consider brand to account as their initial capital because powerful brands have the tendency to upsurge consumers' trust pertaining to their goods as well as services.

Whereas, according to KPMG (2009), a name of a brand plays an imperative part in the course of selling goods and services as consumer recognize brands with features that are favorable to them based on their appeal. For instance, every brand is customarily recognized for its dependence, quality, value, appearance or/and safety and consumers usually buy an automobile based on those features. Therefore, strategic communicational publicity impacts favorable development of the image of a brand as well as brand's recognition. With the 
development of eWOM, communicational publicity has increased rapidly to new heights as well as further strengthened the image of a brand (Serkan \& Gokhan, 2005). Whereas, according to East et al. (2007), the image of a brand immensely impacted choices made by consumers as well as buying intention that consequently leads to selection of a brand.

As per Dellarocas (2003), Electronic social podiums and networks have supported the dissemination of eWOM that kept it distant from the orthodox WOM due to its unparalleled reachability, ability of eWOM's creators to regulate and oversee its eWOM activities as well as special characteristics of interactions that is virtual. What's more astonishingly vital is the internet's ability to communicational interactivity on a bigger gauge. eWOM has been a ground breaking technology for people since the anthropological history, consumers are able to share their individual point of view, thought as well as reactions to users of internet around the globe, as shared communication led to electronic contrivance of response to support numerous activities that incudes developing brands, advancements of products, acquirement of customers, control of quality as well as guarantee of resource quality.

Earlier researches pertaining eWOM's impact are somehow varied on both goods as well as services. According to Lee et al (2009), behavior towards brand is impacted through feedback. Whereas the existence of feedback that is strongly positive impacts a positive assertiveness to a brand in a situation where there are no comments, whereas, commentaries that are unfavorable, average nor too varying, unfavorably impacts on the behavior to the brands. Whereas, according to a research conducted by Chiou and Cheng (2003), unfavorable comments undesirably impacts the behavior as well as the assessment towards goods, however if they have unfavorable brand image. Likewise, a research by Lee and Cranage (2014) also finds significant amount of behavior variation towards unfavorable eWOM in a situation where high consent of evidence is available compared to low consent of evidence is available. In contrast, according to a research conducted by Sandes and Urban (2013) on the impact of eWOM advertisement towards behavior of consumers, the research demonstrated publicity of whatever remark impacts the brand image.

Whereas, according to World Intellectual Property Report (2013), the image of a brand has the tendency to impact firm's earning, consumers' intention to buy as well as their marketing's success which all will consequently impact their sustainability in the long run. In this perspective, as WOM have a vital impact to the intention of purchasing a product, eWOM have a further higher impact on the image of the product as well as the intention to purchase the product of a brand due to its global proximity of disseminating information (Filieri \& McLeay, 2014; Smith, Menon, \& Sivakumar, 2005; Senecal \& Nantel, 2004).

\section{P1. eWOM has a significant impact on brand image.}

\subsection{Purchase intention}

According to Liu and Park (2015), Bronner and de Hoog (2011) as well as Zhang et al (2010), consumers rely upon eWOM to reduce avowed risk. As a matter of fact, Nielsen Research (2013), stated that buyers significantly rely on the consumer views that are online before buying. Moreover, it is the second most prominently dependable source of evidence after friends' recommendation that is initially dependable upon. Furthermore, consumer views that are online significantly influences choices undertaken by buyers (Filieri \& McLeay, 2014; Smith, Menon, \& Sivakumar, 2005; Senecal \& Nantel, 2004) as well as various types of products sales (Cui, Lui, \& Guo, 2012; Zhu \& Zhang, 2010; Ye, Law, \& Gu, 2009; Dellarocas, Zhang, \& Awad, 2007; Liu, 2006; Godes \& Mayzlin, 2004). The impact of online consumer review by consumers is so immense on decision made by consumers that various firms, for instance Kia-Motors currently hosts reviews on their online portal to allow their automobiles to be discoursed by consumers as well as utilize online assessments to be portrayed on their television commercials (Kia Motors, 2014) to portray their brand image so they can induce consumers to purchase their automobiles.

According to Litvin et al. (2008), information as well as assessments that has been disseminated through WOM enabled consumers to be able to help other prospects on their decision of selecting a good or service. Despite the fact that increase of purchase probability increases by means of PWOM, decrease of purchase probability increases by means of NWOM effect (Luo and Zhong, 2015; Park \& Nicolau, 2015; Litvin et al., 2008). Both Luo and Zhong (2015) and Litvin et al (2008) fond eWOM to be dependable as well as unprejudiced means of obtaining evidence. Moreover, they both argued consumers' anticipation, inclinations as well as behavior are shaped through eWOM impacts on their choices as well as their after use assessments. Whereas, according to Park et al. (2007), consumers are highly influenced by the high volume of comments as well as consumer 
evaluations, as it portrays the number of consumers who have bought the good, that consequently justifies their conduct of obtaining the good.

According to a research conducted by Luo and Zhong (2015) that investigates on the aspect of how eWOM through virtual social platforms are impacted by social relations and interaction, found that the strength of social bonds' whether strong, neutral or poor have the tendency to have an impact on eWOM. Moreover, they have also found that, attitude as well as determination of choices is impacted by eWOM through social connections that are robust.

According to Forman et al. (2008), in a connected surrounding, consumers' are greatly impacted towards the perspective they have on a review from the restricted particulars of consumers available online such as the disclosed name and photo as well as the community's online recognition. Apart from that, existing literatures have discoursed on the vitality of arithmetical assessments pertaining to consumers' review given by people who read and analyze their impact towards the course of buying decision (Poston \& Speier, 2005), sale of goods (Duan, et al., 2008) and searching cost (Todd \& Benbasat, 1992). Yet, academics contended that, researches that are quantitative on reviews that are online are able to enlighten a minor facet of a comment's value as few clues are available for a prospect consumer to differentiate among various comments. Therefore, academics propose that studies should be approached by merging both quantitative (ex. Assessment of stars and review length) as well as qualitative (ex. review readability, satisfaction perceived) factors to be able to better illustrate the seeming worth of reviews that are online (Mudambi \& Schuff, 2010; Van der Heijden, 2003).

According to Mudambi and Schuff (2010) research pertaining to usefulness of reviews centered upon testimonials that usefulness to be a measure pertaining the value that is perceived during the choice making situation reflecting diagnosticity of reviews that are online. The research found there is positive optimistic effect of depth of a review lead to positive effect towards expected review helpfulness. Whereas, according to a research conducted by Baek, Ahn, and Choi (2013) whereby they researched pertaining to credibility of review by undertaking review investigation through text mining. As per the theory of dual-process, the results were consumers have a tendency to pay attention to various source of information related to reviews. Precisely, outlaying signals such as assessment of stars and review length tend to be helpful when in the process of searching for information while processing of fundamental evidence such as overall review words as well as the words that are negative from the review, plays an influencing role during the selection of choices. Whereas, according to $\mathrm{Hu}$, Liu, and Zhang (2008), they found that reviews that are online portrays quality of a good as well as minimizes good's ambiguity that consequently aids in making the last decision pertaining to the purchase.

As per Chevalier and Mayzlin (2006) research on assessing the relation amid sale of goods and reviews for an organization that is online retailer that is well-known globally named amazon and another organization that is a well-known book seller named Barnes \& Nobel, their results indicated that reviews by consumers are positively related to sale of goods. While, other researchers, Dellarocas et al (2007) found mean arithmetical rating which can also be identified as valence. Likewise, another research conducted by Duan et al (2008) found the amount of reviews that were stated by online consumers were important movie sales forecaster. Whereas, Clemons, Gao and Hitt (2006) discovered that apart from amount of reviews, reviews that are strongly positive lead to a vital influence to the intention of purchase. Moreover, according to Forman et al (2008), besides amount of reviews that are available online, the level that reviewers reveal who they are when they evaluate the quality of a good impacts on the intention of consumer to purchase.

According to Herr et al. (1991), they contended that information that is unfavorable is diagnostically better as the occurrence is normally minimal compared to information that is favorable or neutral. Likewise, Arndt (1967) discovered that NWOM as influential in altering intention of consumers to purchase, as NWOM is commonly unexpected, it makes greater impact. In addition to that, negative communications comprises limited traits (Mizerski, 1982) that persuades consumers to be further convincing which consequently enables it to have stronger impact (Skowronski \& Carlston, 1989).

Another researcher by the name of Chatterjee (2001) studied the impact of unfavorable views towards a retailer pertaining to assessment and intention to buy. The researcher found unfavorable views generally had unfavorable impact towards the dependability of the retailer as well as the intention to buy. Furthermore, the impacts of unfavorable views were stronger on less reputable retailer compared to retailers that are highly reputable. Whereas according to a research that was undertaken by Sen and Lerman (2007) on how attitude of consumers are impacted by reviews that are mentioned by consumers at online, they have scrutinized that reviews' valence 
which is in other words, the negativity of positivity of a review had a powerful impact on the attitude of consumers pertaining to good that was reviewed.

Though there are antagonistic proofs, academicians as well as managers have similar views pertaining to the fact that PWOM has less impact compared to NWOM (East, et al., 2008). Since decades ago, Arndt (1967) discovered PWOM to have half the impact NWOM had. Moreover, earlier researchers have found NWOM to be unexpected which consequently drove further courtesy (Xia \& Bechwati, 2008), scatter quicker (Libai, et al., 2013) as well as highly believed and relied (Chen, et al., 2011). Whereas, according to a research by Keller (2007), WOM review from consumers that are primary have a propensity of communicating information that is favorable pertaining to what have involved themselves at, as they prefer associating favorable features (Wojnicki \& Godes, 2008), personal augmentation and presentation of their selves (Schau \& Gilly, 2003; Ceema \& Kaikati, 2010; Zhang, Feick, \& Mittal, 2014).

While many researchers found NWOM to have higher impact compared to PWOM, East et al (2008) discovered PWOM highly impacted receivers (64\%) pertaining to the decision of making of a purchase compared to NWOM receivers (48\%) which is similar to the outcomes of Schindler and Bickart's (2002) whereby they found that reviews that are valuable comprised higher favorable comprehensive evidence while few evidence that are unfavorable, that denotes PWOM have greater impact than NWOM, this also supports the findings of Zajonc (1968) that found communication has favorable prejudices. The findings can be likewise as individuals anticipate consumers to be averagely optimistic East et al., 2008; Skowronski \& Carlston; 1989). Apart from that, according to Maio and Haddock (2007), the concept of social-judgment contends the process of assimilation impacts the way the message is viewed by the consumers as they associate their previous circumstance. Thus in an overview, eWOM communications enables an individual to have an impact on the purchasing intention of consumers based on the information illustrated. Henceforth, communication through eWOM immensely impacts the attitude of a consumer while making a buying decision.

\section{P2. eWOM has a significant impact on purchase intention.}

\subsection{Effect of brand image on the relationship between eWOM and purchase intention}

Throughout the decades organizations have been increasingly spending upon brand establishment and development. As we realized the importance of eWOM in the course of purchase intention, the eminent status of brand image asks for verification on its influence on the perceived relationship of eWOM on purchase intention. Generally, establishing a brand means utilizing various communicational tools to communicate an organizations' brand image that would appeal a targeted segment. Kotler (2001) referred brand image as "the set of beliefs, ideas, and impression that a person holds regarding an object" (p. 273). Whereas, Aaker (1991) referred brand image as "a set of associations, usually organized in some meaningful way" (p. 109). While, Keller (1993) refereed brand image to be "a set of perceptions about a brand as reflected by brand associations in consumer's memory" (p. 3). Whereas, Biel (1992) however defined brand image as "a cluster of attributes and associations that consumers connect to the brand name".

Based on the work of Aaker (1991), Keller (1993) conceptualized behavior of Customer Based Brand Equity (CBBE) into two perspectives, of which, one is brand awareness while the other one is brand image. Brand image constituted traits and advantages pertaining a brand that makes it different form the other brands, which consequently gives competitive advantage to a brand (Webster \& Keller, 2004). Traits are basically expressive factors which a brand is defined with. For instance, what consumers perceives towards a brand pertaining to what it is, capabilities, its involvement when consumed or purchased. An advantage of a brand is individual worthiness a consumer attributes to the brand, which in other words can be what a consumer believes to benefit from possessing the brand (Keller, 1993, 1998).

From the perspective of a firm to a customer relation, every dealing an organization has to a customer, inputs are added to the image of a brand. As brands converse an assurance in providing specific form of capabilities, organizations need to be vigilant in understanding the obligations they are obliged by the consumers concerning delivery consistency, predictability as well as quality of performance (Webster \& Keller, 2004). In an environment where business firms transact with consumers, firms encounter grim commotion when they do not attain the anticipations of the consumers. As a result, consumers tend to depend on few dependable brands that supply goods that are in higher value (quality) (Cousins \& Menguc, 2006). Conversely, firms depend upon few targeted consumers to obtain their returns from. The fundamental objective for a firm's brand is to induce trust outlook, safety, assurance, power, recognition, dependability, exclusiveness as well as sustainability (Aaker, 1996; Keller, 1993). 
While HTC smartphone that was based on windows operating system was to be revealed, one thousand customers of T-Mobile were recruited to assess HTC's smartphone through review sites, Twitter and Facebook comments, they found that the discourse of HTC's smartphone through reviews reached over two hundred and thirty four thousand consumers online and have consequently increased the awareness of HTC's brand (Cavoli, 2010). While when Latte Lite was introduced by Dunkin' Donuts, they utilized WOM of three thousand consumers to disseminate the news of their latest drink that reached 111,272 consumers during the span of four months and has boosted the awareness of Dunkin' Donuts' brand (Cavoli, 2010). All the examples demonstrated the vitality of eWOM as a tool in influencing decision of purchase (Guernsey, 2000). The dependability of eWOM among consumers has higher impact than commercials, because consumers are regarding other consumers' view to be dependable upon (Piller, 1999). Therefore, firms possess higher propensity to sales when they receive positive eWOM (Chevalier \& Mayzlin, 2006). Despite the fact that consumers induct eWOM, firms should utilize the online marketing channels by coming up with initiatives to increase eWOM discourse among consumers (Godes \& Mayzlin, 2009).

Even though studies have shown equity of a brand has a tendency to impact on the intention to buy at numerous perspectives (Chang and Liu, 2009; Ashill and Sinha, 2004), various researches that measured the impact brand image towards intention to purchase are very few. As per Wang and Yang's (2010) study relating to credibility of brand effects' towards brands' intention to purchase by consumers pertaining the automobile sector of China, the research has shown that recognition of a brand as well as the image of a brand contributed moderate effect in the correlation. On the other hand, a study that was undertaken by Bian and Moutinho (2011) to examine the effect relating to expected image of a brand, related as well as unrelated impact pertaining to goods' association as well as knowledge towards intention of consumer to buy forged goods through the perspective of non-misleading forgery, they found that, image of a brand is not an intermediary pertaining to the impacts knowledge/association has towards intention to purchase.

Whereas, according to a study undertaken by Wu et al. (2011) pertaining the direct impact image of retail and quality of service has upon image of a brand and intention to purchase towards a brand that is private labeled, their research found image of retail is directly and favorably impact towards image of brand as well as intention to purchase. Moreover, they also found that quality of a service directly and favorably impacted the image of brand. Besides that, according to a study researched by Shukla (2010) pertaining to the effect of individual's impact, origin of brand and image of brand towards luxury purchase intention, the researcher found that relational influence as well as signs of brand impact intention of luxury purchase among consumers. Moreover, the researcher also found that, as normative relational influence are substantial. In addition to that, the researcher also found that image of brand to be impactful moderator amid normative relational influence and intention of luxury purchase among consumers. Therefore, from the studies, Brand Image significantly influences the relationship between eWOM and Purchase Intention.

\section{P3. Brand Image significantly influences the relationship between Electronic Word-of-Mouth and Pur- chase Intention.}

\subsection{Hypothesis summary}

P1. eWOM has a significant impact on brand image.

$\mathrm{P} 2$. eWOM has a significant impact on purchase intention.

P3. Brand Image significantly influences the relationship between Electronic Word-of-Mouth and Purchase Intention.

\subsection{Conceptual framework}

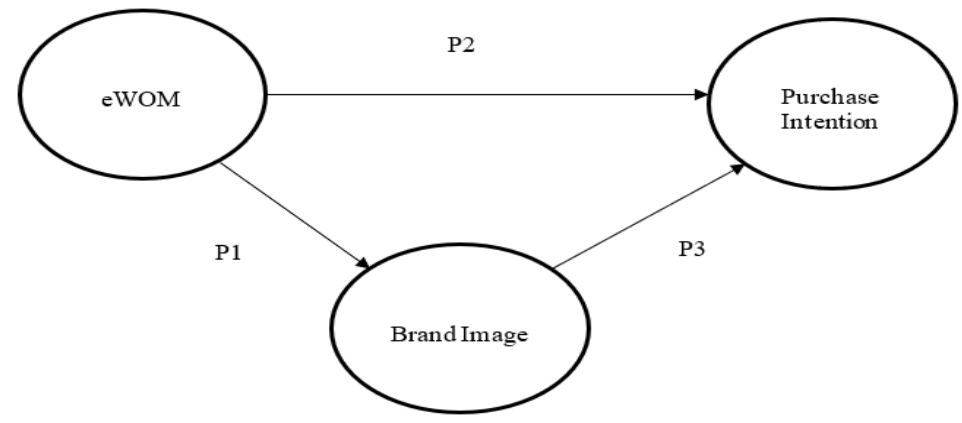

Figure 1. Research framework 


\section{Conclusion}

Researches demonstrated WOM communications to have greater impact compared to other mediums of communication such as ads, that was justified to the reason that trustable information are obtained through WOM communications. Apart from that, research also shows that only $14 \%$ of consumers believe on what ads advertise.

This study has been able to insight to the reader and users practitioners the most fundamentals of this paper. The background study gave an insight of the whole research. Moreover, the gaps were clearly identified in the problem statement and through a proper identification of the research objectives and questions; the paper was able to explain on how the gaps are going to be closed. Moreover, the significance of the study was also elaborated and it explained how this research paper will benefit the academia, automobile companies as well as the government. Lastly, the limitations and scope of the study were also clearly elucidated.

\section{References}

1. Aaker, D. (1991). Managing Brand Equity: Capitalizing on the Value of a Brand Name. New York: The Free Press.

2. Andrew, K. \& Cheema, A. (2010). The Effect of Need for Uniqueness on Word-of-mouth. Journal of Marketing Research, 4(7), 553-563.

3. Arndt (1967). Role of product-related conversations in the diffusion of a new product. Journal of Marketing, 291-295.

4. Automotive Institute of Malaysia (2009). The Malaysian Automotive Industry. Putra Jaya: Ministry of International Trade and Industry.

5. Baek, H., Ahn, J. \& Choi, Y. (2013). Helpfulness of online consumer reviews: readers' objectives a d review cues. International Journal of Electronic Commerce, 17(2), 99-126.

6. Bambauer-Sachse, S. \& Mangold, S. (2011). Brand equity dilution through negative online word-of-mouth communication. Journal of Retailing and Consumer Services, 18, 38-45.

7. Bian, X. \& Moutinho, L. (2011). The role of brand image, product involvement, and knowledge in explaining consumer purchase behaviour of counterfeits: direct and indirect effects. European Journal of Marketing, 45(1/2), 191.

8. Biel, A. (1992). How brand image drives brand equity. Journal of Advertising Research, 32(6), 6-12.

9. Bronner, F. \& Hoog, R. (2011). Vacationers and eWOM: Who Posts, and Why, Where, and What? Journal of Travel Research, 50(1), 15-26.

10. Browning, V. \& Sparksa, B. (2011). The impact of online reviews on hotel booking intentions and perception of trust. Tourism Management, 32(6), 1310-1323.

11. Ceema, A. \& Kaikati, A. (2010). The effect of need for uniqueness on word of mouth. Journal of Marketing Research, 47(3), 553-563.

12. Chang, H. \& Liu, Y. (2009). The impact of brand equity on brand preference and purchase intentions in the service industries. The Service Industries Journal, 29(12), 1687.

13. Chatterjee, P. (2001). Online reviews:do consumers use them? Advances in Consumer Research, 28(1), 129-133.

14. Chen, Y., Wang, Q. \& Xie, J. (2011). Online social interactions: A natural experiment on word of mouth versus observational learning. Journal of Marketing Research, 48(2), 238-254.

15. Chen, Y. \& Xie, J. (2008). Online consumer review: word-of-mouth as a new element of marketing communication mix. Management Science, 54(3), 477-491.

16. Chevalier, J. \& Mayzlin, D. (2006). The effect of word of mouth on sales: online book reviews. Journal of Marketing Research, 79(9), 345-354.

17. Chiou, J. \& Cheng, C. (2003). Should a company have message boards on its websites? Journal of Interactive Marketing, 17(3), 50-61.

18. Clemons, E., Gao, G. \& Hitt, L. (2006). When online reviews meet hyper differentiation: a study of the craft beer industry. Journal of Management Information, 23(2), 149-171.

19. Cousins, P. \& Menguc, B. (2006). The implications of socialization and integration in supply chain management. Journal of Operations Management, 24(5), 604-620.

20. Cui, G., Lui, H. \& Guo, X. (2012). The effect of online consumer reviews on new product sales. International Journal of Electronic Commerce, 17(1), 39-58.

21. Davis, D., Golicic, S., \& Marquardt, A. (2009). Measuring brand equity for logistics services. The International Journal of Logistics Management, 20(2), 201-212. 
22. Dellarocas, C. (2003). The digitization of word of mouth: promise and challenges of online feedback mechanisms. Management Science, 49(10), 1407-1424.

23. Dellarocas, C., Zhang, X. \& Awad, N. (2007). Exploring the value of online product reviews in forecasting sales: The case of motion pictures. Journal of Interactive Marketing, 21(4), 23-45.

24. Drebee, H., Razak, N. \& Karim, M. (2014). Is There an Overlapping Market between National Car Producers in Malaysia?. Jurnal Ekonomi Malaysia, 48(1), 75-85.

25. Duan, W., Gu, B. \& Whinston, A. (2008). The dynamics of online word-of-mouth and product salesdan empirical investigation of the movie industry. Journal of Retailing, 84(2), 233-242.

26. East, R., Hammond, K. \& Lomax, W. (2008). Measuring the impact of positive and negative word of mouth on brand purchase probability. International Journal of Research in Marketing, 27, 215-224.

27. East, R., Hammond, K. \& Wright, M. (2007). The relative incidence of positive and negative word of mouth: A multi category study. International Journal of Research in Marketing, 24, 175-184.

28. Fang, Y. (2014). Beyond the credibility of electronic word of mouth: Exploring eWOM adoption on social networking sites from affective and curiosity perspective. International Journal of Electronic Commerce, 18(3), 67-102.

29. Filieri, R. \& McLeay, F. (2014). E-WOM and Accommodation: An Analysis of the Factors That Influence Travelers' Adoption of Information from Online Reviews. Journal of Travel Research, 53(1), 44-57.

30. Forman, C., Ghose, A. \& Wiesenfeld, B. (2008). Examining the relationship between reviews and sales: the role of reviewer identity disclosure in electronic markets. Information Systems Research, 19(3), 291-313.

31. Fornell, C. \& Larker, D. (1981). Evaluating Structural Equation Models with Unobservable Variables and Measurement Error. Journal of Marketing Research, 18(1), 39-50.

32. Gardner, B. \& Levy, S. (1995). The Product and the Brand. Harvard Business Review, 33, 33-39.

33. Godes, D. \& Mayzlin, D. (2004). Using online conversations to studyword of mouth communication. Marketing Science, 23(4), 545-560.

34. Godes, D. \& Mayzlin, D. (2009). Firm-created word-of-mouth communication: evidence from a field test. Marketing Science, 28(4), 721-739.

35. Harun, A. et al. (2007). The effect of brand image on overall satisfaction and loyalty intention in the context of color cosmetic. Asian Academy of Management Journal, 12(1), 83-107.

36. Hennig-Thurau, T., Gwinner, K., Walsh, G. \& Gremler, D. (2004). Electronic word-of-mouth via consumer-opinion platforms: what motivates consumers toarticulate themselves on the Internet? Journal of Interactive Marketing, 18(1), 38-52.

37. Hennig-Thurau, T. \& Walsh, G. (2003). Electronic word-of-mouth: motives for and consequences of reading customer articulations on the internet. International Journal of Electronic Commerce, 8(2), 51-74.

38. Hu, N., Liu, L. \& Zhang, J. (2008). Do online reviews affect product sales? The role of reviewer characteristics and temporal effects. Information Technology and Mangement, 9(3), 201-214.

39. Jaafar, S., Lalp, P. \& Naba, M. (2013). Consumers' Perceptions, Attitudes and Purchase Intention towards Private label Food Products in Malaysia. Asian Journal of Business and Management Sciences, 2(8), 73-90.

40. Jalilvand, M. \& Samiei, N. (2012). The impact of electronic word of mouth on a tourism destination choice. Internet Research, 22(5), 591-612.

41. Jeong, E. \& Jang, S. (2011). Restaurant experiences triggering positive electronic word-of-mouth (eWOM) motivations. International Journal of Hospitality Management, 30(2), 356-366.

42. Keller, E. (2007). Unleashing the power of word of mouth: Creating brand advocacy to drive growth. Journal of Advertising Research, 47(4), 448-452.

43. Keller, K., 1993. Conceptualizing, measuring, and managing customer-based brand equity. Journal of Marketing, 57(1), 1-22.

44. Lee, C. \& Cranage, D. (2014). Toward Understanding Consumer Processing of Negative Online Word-ofMouth Communication: The Roles of Opinion Consensus and Organizational Response Strategies. Journal of Hospitality \& Tourism Research, 38(3), 330-360.

45. Libai, B., Muller, E. \& Peres, R. (2013). Decomposing the value of word-of-mouth seeding programs: Acceleration versus expansion. Journal of Marketing Research, 50(2), 161-176.

46. Litvin, S., Goldsmith, R. \& Pan, B. (2008). Electronic word-of-mouth in hospitality and tourism management. Tourism Management, 29, 458-468.

47. Liu, Y. (2006). Word of mouth formovies: Its dynamics and impact on box office revenue. Journal of Marketing, 70(3), 74-89. 
48. Liu, Z. \& Park, S. (2015). What makes a useful online review? Implication for travelproduct websites. Tourism Management, 47, 140-151.

49. Lovett, L., Peres, R. \& Shachar, R. (2013). On brands and word-of mouth. Journal of Marketing, 50(4), 427-444.

50. Luo, Q. \& Zhong, D. (2015). Using social network analysis to explain communicationcharacteristics of travel-related electronic word-of-mouth on social networking sites. Tourism Management, 46, 274-282.

51. Maio, G. \& Haddock, G. (2007). Social Psychology: A Handbook of Basic Principles. New York: Guilford.

52. Martin, C. \& Leug, E. (2011). Modeling word-of-mouth usage. Journal of Business Research, 1-8.

53. Mauri, A. \& Minazzi, R. (2013). Web reviews influence on expectations and purchasing intentions of hotel potential customers. International Journal of Hospitality Management, 34, 99-107.

54. Meiners, N., Schwarting, U. \& Seeberger, B. (2010). The Renaissance of Word-of-Mouth Marketing: A 'New' Standard in Twenty-First Century Marketing Management? International Journal of Economic Science Research, 3(2), 79-97.

55. Mizerski, R. (1982). An attribution explanation of the disproportionate influence of favorable and unfavorable information. Journal of Consumer Research, 9(3), 301-310.

56. Munar, A. \& Jacobsen, J. (2014). Motivations for sharing tourism experiences through social media. Tourism Management, 43, 46-54.

57. Nakhaee, A. \& Kheiri, B. (2012). The effect of selected factors on purchase intention for buying green products. Journal of Marketing Management, 15, 105-130.

58. Padgett, D. \& Allen, D. (1997). Communicating experiences: A narrative approach to creating service brand image. Journal of Advertising, 26(4), 49-62.

59. Park, C., Jaworski, B. \& Maclnnis, D. (1986). Strategic brand concept-image management. Journal of Marketing, 50(4), 135-145.

60. Park, D., Lee, J. \& Han, I. (2007). The effect of on-line consumer reviews on con-sumer purchasing intention: the moderating role of involvement. International Journal of Electronic Commerce, 11(4), 125-148.

61. Park, S. \& Nicolau, J. (2015). Asymmetric effects of online consumer reviews. Annals of Tourism Research, 50, 67-83.

62. Poston, R. \& Speier, C. (2005). Effective use of knowledge management systems: a process model of content ratings and credibility indicators. MIS Quarterly, 29(2), 221-244.

63. Punj, G. (2013). Do consumers who conduct online research also post online reviews?: A model of the relationship between online research and review posting behaviour. Marketing Letters, 4(1), 1-17.

64. Riegner, C. (2007). Word of Mouth on the Web: The Impact of Web 2.0 on Consumer Purchase Decisions. Journal of Advertising Research, 47(4), 436-447.

65. Sandes, F. \& Urdan, A. (2013). Electronic Word-of-Mouth Impacts on Consumer Behavior: Exploratory and Experimental Studies. Journal of International Consumer Marketing, 25(3), 181-197.

66. Schau, H. \& Gilly, M. (2003). We are what we post? Self-presentation in personal web space. Journal of Consumer Research, 30(3), 385-404.

67. Senecal, S. \& Nantel, J. (2004). The influence of online product recommendations on consumer's online choices. Journal of Retailing, 80(2), 159-169.

68. Sen, S. \& Lerman, D. (2007). Whyareyoutellingmethis? An examination into negative consumer reviews on the web 21. Journal of Interactive Marketing, 21(4), 76-94.

69. Serkan, A. \& Gokhan, O. (2005). National customer satisfaction indices: an implementation in the Turkish mobile telephone market. Marketing Intelligence \& Planning, 23(5), 486-504.

70. Serra Cantallops, A. \& Salvi, F. (2014). New consumer behavior: a review of research oneWOM and hotels. International Journal of Hospitality Management, 36, 41-51.

71. Shukla, P. (2010). Impact of interpersonal influences, brand origin and brand image on luxury purchase intentions: measuring interfunctional interactions and a cross-national comparison. Journal of World Business, 46(2), 242-252.

72. Skowronski, J. \& Carlston, D., (1989). Negativity and extremity biases in impression formation: a review of explanations. Psychological Bulletin, 105(1), 131-142.

73. Smith, D., Menon, S. \& Sivakumar, K. (2005). Online peer and editorial recommendations, trust and choice in virtual markets. Journal of Interactive Marketing, 19(3), 15-37.

74. Sweeney, J., Soutar, G. \& Mazzarol, T. (2012). Word of mouth: measuring the power of individual messages. European Journal of Marketing, 46(1), 237-257. 
75. Tavakol, M. \& Dennick, R. (2011). Making sense of Cronbach's alpha. International Journal of Medical Education, 2, 53-55.

76. Todd, P. \& Benbasat, I. (1992). The use of information in decision making: an experimental investigation of the impact of computer-based decision aids. MIS Quarterly, 16(3), 373-393.

77. Tsai, S. (2011). Strategic relationship management and service brand marketing. European Journal of Marketing, 45(7), 1194-1213.

78. Van der Heijden, H. (2003). Factors influencing the usage of websites: the case of a. Information \& Management, 40(6), 541-549.

79. Wang, X. \& Yang, Z. (2010). The effect of brand credibility on consumers' brand purchase intention in emerging economies: the moderating role of brand awareness and brand image. Journal of Global Marketing, 23(3), 177.

80. Webster, F. \& Keller, K. (2004). A roadmap for branding in industrial markets. Brand Management, 11(5), 388-402.

81. Wu, P., Yeh, G. \& Hsiao, C. (2011). "The effect of store image and service quality on brand image and purchase intention for private label brands. Australasian Marketing Journal, 19, 30-39.

82. Xia, L. \& Bechwati, N. (2008). Word of mouse: The role of cognitive personalization in online consumer reviews. Journal of Interactive Advertising, 9(1), 3-13.

83. Xie, H., Miao, L., Kuo, P. \& Lee, B. (2011). Consumers' responses to ambivalent onlinehotel reviews: the role of perceived source credibility and pre-decisional dispo-sition.. International Journal of Hospitality, 30, 178-183.

84. Yao, Y., Dresner, M. \& Palmer, J. (2009). Private network EDI vs. Internet electronic markets: a direct comparison of fulfillment performance. Management Science, 55(5), 843-853.

85. Ye, Q., Law, R. \& Gu, B. (2009). The impact of online user reviews on hotel room sales. International Journal of Hospitality Management, 28(1), 180-182.

86. Yoo, K. \& Gretzel, U. (2008). What motivates consumers to write online travel reviews?. Information Technology \& Tourism, 10, 283-295.

87. Zhang, Y., Feick, L. \& Mittal, V. (2014). How males and females differ in their likelihood of transmitting negative word of mouth.. Journal of Consumer Research, 40(6), 1097-1108.

88. Zhang, Z., Yea, Q., Law, R. \& Li, Y. (2010). The impact of e-word-of-mouth on the online popularity of restaurants: A comparison of consumer reviews and editor reviews. International Journal of Hospitality Management, 29(4), 694-700.

89. Zhu, F. \& Zhang, X. (2010). Impact of online consumer reviews on sales: The moderating role of product and consumer characteristics. Journal of Marketing, 74(2), 133-148. 